\title{
18. Yüzyılın İlk Yarısında Kudüs Sancağında Merkez ve Çevre iliş̧kisi Bağlamında Osmanlı Devleti ve Yerel Güçler*
}

Abdalqader Steih**

\section{Öz}

Devlet, 18. yüzyılın ilk yarısında Kudüs Sancağı'ndaki yönetim yöntemlerini gözden geçirmiştir. Söz konusu yönetim yöntemlerinin başarıya ulaşmasında âyanlar, askeri ağalar ve bedevi kabile şeyhlerinin sancaktaki devlet temsilcileriyle işbirliği içinde olması etkili olmuştur. Bu çalışma, devletin, arabuluculuğun ötesinde katkıları olan âyanları koordine etmesindeki başarısının yanı sıra sancağın içindeki ve dışındaki görevlerin ifasında devletin emirlerini yerine getiren ve disiplinini kaybetmiş yerel askeri güçlerle denge unsuru oluşturan icracı askeri bir güç tesis etmesindeki başarısını ortaya koymaktadır. Bu çalışma ayrıca devletin, sancağın çevresine dağılmış bedevi kabileleri Hac yoluna bağlı yolların güvenliğinden sorumlu tutma ve onların yerleşim birimlerinden uzak durmalarını sağlama konusundaki kısmî başarısını da ortaya koymaktadır. Çalışmada, modern sancak tarihindeki bedevi, asker ve âyan ailelerinin etkin veya zayıf rollerinde 18. yüzyllın ilk yarısında devlet ile yerel güçler arasındaki ilişkilerin büyük etkisi olduğu sonucuna varılmıştır.

Anahtar Kelimeler: Âyan, yerel askerler, bedevî kabileler, hac kafilesi, cerde.

\section{The Ottoman State and the Local Forces in the Province of Sanjak of Jerusalem in the First Half of the Eighteenth Century: Relations in the Center and Surroundings}

\section{Abstract}

The state has reviewed its state crafts in the sanjak of Jerusalem in the first half of the 18 th century. Being the ayans, military headmen and bedouin tribal sheikhs in cooperation with the banner state representative has been effective in the success of the relevant statecrafts. This study puts forward the success of the state in coordinating the ayans which had contribution beyond conciliation and building up an executing military power

* Bu çalışma Marmara Üniversitesi Türkiyat Araştırmaları Enstitüsü, Türk Tarihi Ana Bilim Dalı, Yeniçağ Tarihi Bilim Dalı'nda, Prof. Dr. Ahmet Şimşirgil (I. Danışman) ve Prof. Dr. Zekeriya Kurşun (II. Danışman) danışmanlıklarında sürdürülen doktora çalışmasından üretilmiştir.

** Doktora öğrencisi, Marmara Üniversitesi Türkiyat Araştırmaları Enstitüsü Türk Tarihi Ana Bilim Dalı Yeniçağ Tarihi Bilim Dalı, İstanbul/Türkiye, qadersteeh@yahoo.com 
that equipoise undisciplined local military forces who fulfill the orders of the state during the performance of duties within and outside the banner. Moreover this study sets forth the partial success of the state in providing the Bedouin tribes scattered around the banner in holding them responsible for the safety of the linking roads of the pilgrimage route and ensuring them to stay away from residential areas. It has been concluded from the study that there is a big impact of the relationship between the state and local powers in the active or weak roles of the bedouin, military and ayans' families in the modern banner history in the first half of the 18th century.

Keywords: Ayans, local military, bedouin tribes, hajj convoy, cerde. 


\section{Giriş}

Devlet, 18. yüzyılın ilk yarısında yerel idarecilerin itibarını korumak ve Şam Hac kafilesinin güvenliğini sağlamak için Şam vilayetiyle buraya bağlı olan Kudüs Sancağı'nda mevcut yönetim yöntemlerini gözden geçirmiş ve sancak yönetiminde birçok değişikliğe gitmiştir. Bu bağlamda devlet öncelikle yerel güçlerin sancaktaki işlerini kolaylaştırmak için bunların temsilcileriyle işbirliği yoluna gitmiştir. Bu yerel güçler ise, sancaktaki konumlarını pekiş̧irme yoluna gitmişlerdir. $\mathrm{Bu}$ nedenle iki taraf arasındaki ilişkilerde bir takım çelişkiler ve anlaşmazlıklar hasıl olmuştur. Çalışmada bunlara 1şık tutulmaya çalışılacaktır. Kudüs'ün Osman11 hâkimiyetine girmesinden sonra devletle yerel güçler arasındaki ilişkiler, devletin belirli sınırlar içerisinde yerel güçlerin faaliyetlerine imkân tanıyan göreceli bir uyuma tanık olmuştur. Devlet 17. yüzyıl sonlarında çeşitli cephelerde düşmanlarıyla savaşırken Kudüs Sancağı'yla ilgili işlerin çoğunu takip edememesi, yerel güçlerden bazılarının, devletin belirlediği sınırların dışına çıkmasına yol açmıştır.

Devlet 1699 yılında Şam Vilayeti ile Kudüs Sancağı'ndaki yönetim yöntemlerini gözden geçirme firsatı veren Karlofça Anlaşması'nı imzalamıştır. Bu gözden geçirme işleminin en önemli sonuçlarından birisi de Kudüs Sancağı'nın, idari, ekonomik ve askeri açıdan her yıl Şam Hac kafilesini hicaz dönüşünde karşılayıp ona gerekli erzak ve himayeyi sağlayan Cerde Askeri'ne tahsis edilmesi olmuştur. ${ }^{1} \mathrm{Bu}$ da Kudüs mutasarrıflarının yakın sancaklar üzerinde hakimiyet kurmalarıyla Kapıkulu askerlerinin devlet tarafından kalelere yerleştirilmesini beraberinde getirmiştir. ${ }^{2} 18$. yüzyılın ikinci çeyreğinde ise devlet, sancaklara merkezden mutasarrıf göndermeyi terk etmiş ve yerlilerin sancaktaki yüksek idari mevkilere ulaşmalarına izin vermiştir. ${ }^{3}$ Devlet ayrıca icraatlarında başarı kaydetmek için bedevi kabile şeyhleri, asker ağaları ve şehir âyanları gibi çeşitli gruplara ayrılan sancaktaki yerel güçlerin desteğini almaya çalışmıştır. Çalışmanın hedeflerini gerçekleştirmek için devletin, bunların her biriyle olan ilişkilerine ayrı ayrı yer verilecektir.

\section{1. Âyanlar}

Âyan tabiri, Osmanlı Devleti'nin resmi yazışmalarında da kullanılmıştır. 17. yüzyılın sonlarında Osmanlı Devleti'nde âyan ifadesi en geniş anlamıyla, ileri gelenler ve şöhret sahipleri için kullanılmıştır. Bazen de bu tabirden maksat ilim ehli âlimler olmuştur. ${ }^{4}$

1 BOA, C. AS., 943/ 40932; BOA, C. EV., 515/ 26008.

2 BOA, C. EV., 28003; BOA, TS.MA.d., 3139.74; Kudüs Şeriyye Sicili, ( K.Ş.S.), 201. s. 163; K.Ş.S., 209. s. 176-177; Mehmed Raşid, Tarih-I Raşid, C: V, İstanbul, s. 202-203, 232.

3 Abdülkerim Rafik, "Filistin fi El-Ahd El-Osmani” el-Mevsuâtu'lFilistiniye, C: II, Beyrut -1990, s.703.

4 H.A. Gibb ve harold Bowen, Islamic Society and the west, Cilt: I, Oxford Üniversitesi, 1957, C: I, s.198-199. 
Osmanlı Devleti 18.yüzyılın başlarına kadar yönetimin, Kudüs Sancağı'nda yerli güçlere bırakılmasına müsaade etmemiş; sancak mutasarrıfıyla şeri mahkeme kadısını bir yıllığına kendisi atamıştır. Fakat bunlar, yerli halkın dilini bilmedikleri gibi buraya adapte olacak kadar uzun bir süre ikamet etmiyorlardı. $\mathrm{Bu}$ nedenle sancağın işlerini yürütmek için âyanların yardımına ihtiyaç duymuşlardır. Kudüs'te devlete bağlı dini ve eğitim kurumlarında çalışan kimseler arasında devlet temsilcileriyle halk arasında arabulucu görevini üstlenen alimler ön plana çıkmıştır. Bunlar arasında Vefâî, Ğudayye, Alemî, Hâlidî, Deccânî ve Lutf ailelerine mensup alimler bulunmaktaydı. Bunlar nakibüleşraflık, Hanefî mezhebi müftülüğü, Kudüs harem bölgesi şeyhliği ve kadı vekilliği gibi şehirdeki önemli dini pozisyonlarda görev yapmışlardır. ${ }^{5}$

Âlimlerin yanı sıra nesilden nesile devlet hizmetinde askeri ve idari görevler üstlenen imtiyazlı ve varlıklı ailelere mensup kimseler de ön plana çıkmıştır. Bunlar arasında da şer'i mahkemede tercümanlık, sancak miralaylığı, Kudüs mimarbaşılığı ve Kudüs Kalesi dizdarlığı görevini üstlenen Aselî, Nimrî, Akîl, Kasım ailelerine mensup kimseler ön plana çıkmıştır. ${ }^{6}$

Şehrin âyanları, mutasarrıfın önünde toplumun tümü veya bir kısmı adına konuşabilmeleri için çeşitli devlet kademelerinde sosyal ve politik güç kazand1rarak yönetime ulaştıran önemli görevler üstlenmişlerdir. Onlar bu güçlerini devletin yanı sira yerel toplumun desteğiyle de elde etmişlerdir. Şehir halkı, onları, geleneksel resmi sözcüleri olarak görmüşlerdir. Şehir âyanları sahip oldukları iki güç arasındaki teması koparmamak için toplum karşısında ne salt devletçi ne de devletin önemli mevkilerine ulaşmalarını engelleyecek şekilde devlet düşmanı olarak görünmemeleri gerekiyordu. ${ }^{7}$

Devletin, sancaktaki âyanlara olan güveni 17. yüzyıl sonlarında çeşitli sebeplerden dolayı artmıştır. Bu sebeplerin başında devletin iltizam sistemini geniş yelpazede uygulamasıydı. Bunlar gerek nahiye ve köy şeyhleriyle kurdukları iletişim gerekse sahip oldukları ekonomik güç sayesinde devletin vazgeçemediği kimselerden olmuşlardır. ${ }^{8}$

Devlet 18. yüzyıl başlarında sancakta, vilayet merkezi Şam'da bulunan Şam Hac Kafilesi'nin güvenliğini sağlamak için devletin genel politikası ve icraatlarıyla uygunluk arz eden bir dizi yeni icraatı hayata geçirmeye başlamıştır.

5 Esma Hasavna, Ailet el-Kuds el-mutanefiza fi'l-karn es-sani aşera, basılmamış doktora tezi, Ürdün,Yarmuk Üniversitesi, 2009, s. 5-19.

$6 \quad$ K.Ş.S., 202, s.23 ; K.Ş.S., 203, s.23 ; K.Ş.S., 209, s. 188 ; K.Ş.S., 230, s. 250.

7 El-Bart Havrani, El-Islâhü'l-Osmanî ve Siyasâti'l-Ayân, Mecelletü'l-İctihâd, 2000 (105-142), s. 106-107.

8 K.Ş.S., 200, s.98; K.Ş.S., 208, s.221, 257, 349; El-Bart Havrani, El-bilad Alarapiye fi El-ahd El-Osmani, Dimaşk, 1996, s. 312. 
Şehrin âyanları bu kararlardan bazılarına itiraz etmişlerdir. Osmanlı Devleti'nin, Fransa'nın Sayda konsolosuna Kudüs'te ikamet izni vermesi ${ }^{9}$ ile mutasarrıfa eşlik eden askerlerin sayısının arttırılmasına ${ }^{10}$ itiraz etmeleri buna bir örnektir. Devlet bu itirazlar neticesinde Kudüs'ü Cerde Askeri'nin merkezi yapmış ve devlet temsilcileri, nahiye şeyhleri ve asker ağalarla işbirliği yaparak 1702-1705 yılları arasında âyanların şehre girişlerine izin vermemişlerdir. ${ }^{11}$

İsyana devam edip etmeme konusunda şehir âyanları arasında çıkan anlaşmazlıklara son vermek için 1705 yılında Kudüs Mutasarrıflı̆̆ı'na Mustafa Paşa'y1 getirmiştir. Şam valisi Kürt Mehmet Paşa'nın Mustafa Paşa'ya verdiği büyük askeri destek sayesinde Osmanlı Devleti isyanı bastırarak isyancıları birçok cezaya çarptırmıştır. ${ }^{12}$

Bu olaylar, Osmanlı Devleti’ni; âyanların giderek artan nüfuzlarına sınır koymaya ve etkilerini sadece idareciler ile halk arasında iletişimi sağlamakla sınırlandırmaya yöneltmiştir.Devlet, âyanların en büyük destekçisi olan yerel halk1 kendi safına çekebilmek için bir takım uygulamalarda bulunmuştur. Bu bağlamda Devlet, temsilcilerine yardım edenleri mal ve mevki ile ödüllendirirken kararlarına itiraz edenleri devlet imkanlarından mahrum bırakmıştır. Nakibüleşraf Muhammed Vefai'nin, Misır ve Rum (Anadolu) surrelerindeki tüm gelirlerinin kesilerek aralarında yeni Nakibüleşraf Muhibbuddin Ğudeyye'nin bulunduğu âyanlara dağıtılması buna örnektir. ${ }^{13}$

Devlet şehir âyanlarına yönelik çeşitli cezalar öngörmüş ve devletin izin verdiği arabuluculuk rolünün ötesinde idealler kuranlar hakkında ağır yaptırımlar uygulamıştır. 1707 yılında isyana öncülük yaptığı gerekçesiyle Nakibüleşraf Muhammed Vefai'nin idam edilerek evinin yıkılmasi; ${ }^{14} 1713$ yılında da görevlerini kötüye kullanmaları gerekçesiyle Nakibüleşraf Muhibbuddin Ğudeyye, şeri mahkeme tercümanı Kasım Bey ve oğulları ile bir takım destekçilerini Kıbrıs'a sürgüne göndermesi bunun en bariz örneklerindendir. ${ }^{15}$

On sekizinci yüzyılın ikinci çeyreğinde devlet, idari atamalarda olduğu gibi nakiplik ve müftülük atamalarını yıllık yapmaya başlamıştır. ${ }^{16}$ Böylece şehir

9 K.Ş.S., 200, s. 209-211,245; K.Ş.S., 200, s.209-211; Kâmil Cemil El- Aselî, Vesaik makdisiyye tarihiye, Amman, 1983, C: I, s.291.

10 BOA, A.DVNSŞKT.,d. 37, s.70; K.Ş.S., 203. s.54, 355; Minna Rozen. "the naqib al-ashraf rebellion in Jerusalem and its repercussion on the city's Thimmis".Asian and African Studies, 19, 1984, (249-270), s. 253-254; K.Ş.S., 203, s. 101-102; Muhammed İbn Kennan Es-Salihi, Yevmiyyâtü'ş-Şâmiyye, Dımaşk-T.y., s.45.

11 K.Ş.S., 202. s.51; K.Ş.S., 202, s.479; K.Ş.S., 202, s. 219, 238; Rozen, a.g.m., s. 255-256.

12 K.Ş.S., 203. s. 42-33; 101-102; Hasan El-Hüseyni, Teracim Ehli'l-Kuds fi'lkarn Es-Sani aşera el-Hicrî. Amman, 1985. s.148.

13 K.Ş.S., 203. s.110-142.

14 BOA, A. DVNSŞKT., d. 48, s.480; Raşid. a.g.e., C: III, s.233; K.Ş.S., 203. s.48.

15 K.S.S.S., 207. s. 320.

16 K.Ş.S., 228. s.9, 93, 225; K.Ş.S., 229. s.87; K.Ş.S., 232. s.3, 10, 34,36, 233. 
âyanlarından hiç kimse üzerindeki şiddetli rekabet sebebiyle bu görevlerde uzun süre kalamamışlardır.

18. yüzy1lın ilk çeyreğinde Muhammed Vefai ve Muhibbuddin Ğudeyye olmak üzere sadece iki kişiye verilen nakibüleşraflık görevi, ikinci çeyrekte Feyzullah el-Alemî, Fethullah ed-Deccânî, Süleyman ed-Deccânî, Muhammed Ğudeyye ve Abdüllatif Ğudeyye olmak üzere beş kişiye verilmiştir. ${ }^{17}$

Aynı şekilde Hanefî̀ müftülüğü makamı ilk çeyreğin çoğunluğunda Muhammed b. Abdurrahim'de ${ }^{18}$ iken ikinci çeyrekte bu makamda, Feyzullah el-Alemî, ${ }^{19}$ Ebubekir el-Alemî, ${ }^{20}$ Ahmed el-Muakkat, ${ }^{21}$ Necmeddin er-Remlî̀ ${ }^{22}$ ve Muhammed Ebus'suud $^{23}$ ve Halil el-Beni ${ }^{24}$ görev yapmıştır.

Devlet bu sayede çeşitli ailelere bağlı grupların bu önemli görevler üzerindeki tekeline son vermiş ve Necmettin er-Remlî örneğinde olduğu gibi Kudüs'e yeni yerleşen ailelerin önemli mevkilere gelmelerine müsaade etmiştir. ${ }^{25}$

Âyanlar mevkilerini muhafaza etmek veya yeni görevlere gelebilmek için devletin icraatlarına karşı gelmemeye özen göstermişlerdir. Onlardan birçoğu İstanbul'a giderek bu görevlere atamaları gerçekleştiren yetkililere çeşitli hediyeler takdim etmişlerdir. Çünkü Kudüs nakibüleşrafın1, İstanbul nakibüleşrafi:;6 Kudüs

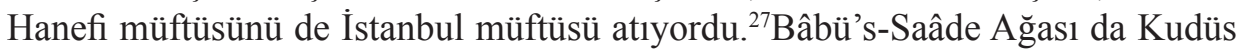
Harem şeyhinin yanı sıra Mescid-i Aksa ve Kubbetü's-Sahra mimarbaşısını atama yetkisine sahipti. ${ }^{28}$

1734 yılında Mescid-i Aksâ'nın Mâlikî mezhebi imamı ve şehrin servet sahibi tüccarlarından biri olan Şeyh Ahmed el-Muakkat da Hanefi mezhebine geçmesinin akabinde İstanbul'a gerçekleştirdiği ziyaretin ardından, Hanefî müftülüğü vazifesini elde etmiştir. ${ }^{29}$ Carullah el-Lutf da Şafi mezhebinden Hanefî̀ mezhebine geçmiş, Hanefî̀ müftüsü olan amcaoğlu Muhammed Lutf'un vefatının ardından bu görevi talep etmek için İstanbul'a gitmiş, ancak arzusuna ulaşamadan vefat etmiştir. ${ }^{30}$

17 Esma Hasavna, a.g.e., s.32-33.

18 K.Ş.S., 201. s. 179; A.g.s., 221. s. 155; Muhammed Halil El- Muradi, Silkü'd-Durar fi Âyan el-karn es-sani aşera, Dimaşk, 1955, C: III, s.52,58.

19 K.Ş.S., 227. s. 234.

20 K.Ş.S., 218. s. 247; El- Muradi, a.g.e., , C: I, s.49.

21 El- Muradi, a.g.e., C: I, s.175.

22 K.Ş.S., 230. s. 238; A.g.s., 232. s. 36.

23 El- Muradi, a.g.e., C: I, s.173.

24 A.g.e., C: II, s.101.

25 K.Ş.S., 230. s. 238; A.g.s., 232. s. 36.

26 Bkz, K.Ş.S., 200. s. 221; K.Ş.S., 232. s.12; El- Muradi, a.g.e., C: II, s.6,13.

27 K.Ş.S., 217. s. 260.

28 Bkz, K.Ş.S., 200. s. 167; K.Ş.S., 202. s. 157 K.Ş.S., 229. s.254.

29 El-Muradi, a.g.e., C: I, s.175.

30 El- Muradi, a.g.e., C: I, s.6. 
Şehirde devam eden Mescid-i Aksa ve Kubbetü’s-Sahra'nın imar işlemleri, âyanların, şehrin imarı için gerekli olan malzemeyi getirdikten sonra Anadolu'ya dönen gemiler yoluyla İstanbul'a ulaşmalarını kolaylaştırmıştır. ${ }^{31}$ Birçok kişiyeni görevlere atanmaya da aralarındaki anlaşmazlıkların çözümü noktasında devletten hakemlik yapmasını istemek için İstanbul'a gidiyordu. Bu durum ise âyanlar arasında ciddi tartışmalara sebep olmuş; mağdur olan halk ise mahkemelere başvurmuştur. Sorunun engellenmesi için kadının izni olmaksızın İstanbul'a gidip, kendine vazife verildiğine dair berat getiren kimselere 50 kuruşluk maddi ceza verilmiştir. ${ }^{32}$

Pek çok âyan, ilim tahsili için İstanbul'a gitmiştir. Çünkü birçok kişi İstanbul'da eğitim almış olmasından dolayı önemli görevler elde etmiştir. Burada eğitim görmeleri neticesinde Şerafeddin Useyli kadılık görevine getirilirken ${ }^{33}$,Ali bin Habîbullah Lutf ve Ahmed Timurtâşî El-Ğazzîde devletin farklı kademelerinde birçok göreve atanmışlardır. ${ }^{34}$ Eğitim süresi içerisinde ilim tahsili için Kudüs'ten İstanbul'a giden âlimler sayı bakımından Şam ve Kahire'den sonra üçüncü sirada gelmekteydi. ${ }^{35}$

Şehrin pek çok âyanı Osmanlıca öğrenmeye yönelmiştir. Muhibbuddin Ğudeyye'nin nakibüleşraflıkta ulaştığı makamı ve diğer görevleri, Osmanlıcayı iyi bilmesi sayesinde elde ettiği söylenebilir. ${ }^{36}$

Şehir âyanlarının birçoğu şehrin büyük vakıflarından sorumlu olan Bâbü's-Saâde Ağası ile iyi ilişkiler kurmaya çalışmışlardır. Bu iyi ilişkiler neticesinde ise kendilerine vakıflarda yeni görevler verilmiştir. Hekari Ailesi'ne ait bir vakıfta boşalan bir görev için tercüman Kasım Bey ataması bu şekilde gerçekleşmiştir. ${ }^{37}$ Kadıya tercümanlık yaparken insanlara zulmettiğine dair aleyhindeki onlarca şikâyete rağmen Bâbü's-Saâde Ağası ile iyi ilişkileri sayesinde görevini muhafaza etmiştir. ${ }^{38}$

Şehir âyanlarından bazıları Şam defterdarıyla iyi ilişkiler kurmuşlardır. Kurulan bu ilişkiler âyanlara görev sahibi olmakta yardımcı oluyordu. Bazen $\mathrm{Mu}$ hibbuddin Ğudeyye'ye ${ }^{39}$ bazen de Şeyh Muhammed Halilî'ye ${ }^{40}$ verilen sancak

31 BOA, C. EV., 27, 1618.

32 K.Ş.S., 225. s. 59-60 ; A.g.s., 227. s. 171.

33 Muhammed El-Muhibbi, Hulasatu'l-esar fi Ayan el-karn el-hadi aşera, Kahire, 1966,C:III, s. 225.

34 Muradi, Silkü'd-Durar, a.g.e., C: III, s. 209.

35 Abdülkerim Rafik, "Filistin fi El-Ahd El-Osmani" el-Mevsuâtu'lFilistiniye, C: II, Beyrut, 1990, s. 731.

36 El-Hüseyni, a.g.e., s. 332.

37 K.Ş.S., 209. s. 150,156; Esma Hasavna, a.g.e., s.107-108.

38 BOA, IE, T., 473;BOA, A. DVNSSSKT., d. 32, s.450, h. 1826.

39 K.Ş.S., 203, s.74, 254, 328; K.Ş.S., 206, s. 165

40 K.Ş.S., 206, s. 601. 
çevresindeki Huristiyanlardan cizye toplama görevi ve Muhammed Halilî ile Tercüman Kasım Bey'e ${ }^{41}$ verilen Mescid-i Aksa ve Kubbetü's-Sahra'nın imarı gibi görevler buna örnek gösterilebilir.

Âyanlardan birçoğu devletin şehre gönderdiği mutasarrıflarla işbirliği yapmaya özen göstermişlerdir. Yaptıkları bu işbirliğin faydasını da görmüşlerdir. Örneğin Muhammed Halîlî, şehrin mutasarrıfı Recep Paşa'nın 1714-1716 yıllarındaki icraatlarını öven bir mektup yazmış; buna mukabil Recep Paşa Mısır Valiliği görevine giderken onu yanında götürmüştür. ${ }^{42}$

Âyanlardan bazıları da devletin gönderdiği kadılarla iyi ilişkiler kurmaya gayret etmiştir. Bu kadılar, kadı vekilliğine, şeri mahkemelere, sancağa bağlı diğer mahkemelere, din ve eğitimle ilgili mevkilere görevli tayin etme hakkını ellerinde bulunduruyorlardı. Kadının, Carullah El-Lutf'u yanına alarak Şam şer'i mahkemesinde kadı vekili olarak göreve almasını sağlaması buna örnektir. ${ }^{43}$

Sancak âyanları, devletin talimatlarına bağlı kalmaları neticesinde yerel destekten büyük oranda mahrum kalmışlardır. 1713'teki Şehrin âyanlarından Nakibüleşraf Muhibbuddin Ğudeyye hakkında çıkarılan sürgün kararı ${ }^{44}$ ayrıca 1760'daki Nakibüleşraf Abdullatif Ğudeyye hakkında uygulanan zorunlu ev hap$\mathrm{si}^{45}$ herhangi bir protestoyla karşılaşmamıştır.

Devletin, çeşitli bölgelerdeki yerli halkın mütesellimlik makamına ulaşmas1na izin vermesinden sonra şehir âyanlarından hiç kimse bu makama ulaşamamıştır. Bu husus ise eğitim süresi içerisinde sancakta bulunan âyanların durumundaki istikrarsızlı̆̆ işaret etmektedir.

Devletin icraatlarına karşı çıkan bazı âyanların ve ailelerinin nüfuzunun azalmasına en bariz örnek, Nakibüleşraf Muhammed el-Vefai'nin idam edilmesinden sonra aile fertlerinden hiç kimsenin Nakibüleşraflığa ya da diğer önemli görevlere gelememesidir. Aynı şeyler, devletin birçok kararına itiraz eden Hanefi müftüsü Abdurrahim Lutf'un tutumları neticesinde Lutf ailesinin başına gelmiştir. ${ }^{46}$ Buna karşılık devlete düşmanlık beslemeyen Kasım ve Ğudeyye ailesi gibi bazı aileler, âyanlar arasında önemli mevkilere gelmişlerdir. 1744 yılında Abdullatif Ğudeyye Nakibüleşraflık ve Harem şeyhliği görevlerini aynı anda yürütme imkânı bulmuştur. ${ }^{47}$ El-Huseynî ismiyle tanınan bu ailenin 19. ve 20. yüzyıldaki şehir tarihinde bariz bir rolü olmuştur. ${ }^{48}$

41 K.Ş.S., 209, s. 255; K.Ş.S., 216, s.100,101.

42 Muhammed El-Halili. Tarihi'l Kuds ve'l-halil. London, 2004.s. 56.

43 El- Muradi, a.g.e., C: II, s.6.

44 K.S..S., 207. s. 320.

45 El- Muradi, a.g.e.,C: III, s. 124.

46 Esma Hasavna, a.g.e., s.25.

47 El- Muradi, a.g.e.,C: III, s. 124.

48 Butrus Abu-Manneh, The Husaynis: The Ris of Notable Family in 18 th Century Palestine on book Daivd Kushner: Palestine in the late Ottoman period, Jerusalem, 1986, s.17. 


\section{Asker Ăgalar}

Askerler, devlet yönetimi veya sancak güvenliği üzerinde doğrudan tehlike oluşturan tek silahlı güç idi. Devletin Kudüs'te kurduğu askeri güçler çeşitlilik arz etmekteydi. Yeniçeriler en önemli gücü oluşturuyordu. Yeniçeriler, güçlerini, yönetim ve yargıdan ayrı bir yapıya sahip oluşlarından alıyorlardı. 1700 yılında sancak mutasarrıfı İvaz Paşa kaleye cebeci başı tayininde bulununca ağalar buna itiraz etti ve kadıdan tayinin iptal edilmesini istediler. Çünkü mutasarrıfın kale içerisindeki tayinlere müdahale yetkisi yoktu. ${ }^{49}$

Yeniçerilerin yanı sıra sancağın güvenliğini sağlayan ve köylere dağılan t1marlı askerler bulunmaktaydı. Bunların yüksek rütbeli olanları şehirde ikamet etmiştir. ${ }^{50} \mathrm{Bu}$ güçlere ilaveten merkezi hükümete bağlı olmayan paralı askerler de vardı. Paralı askerler kendisine ödemeye yapan şahıslara askeri hizmet veriyor ve şehrin farklı bölgelerinde ikamet ediyorlardı. Levent ve Sekban askerleri bu grup içinde öne çıkanlardır. ${ }^{51}$

Yeniçeriler 16. yüzyıl sonlarında şehre yerleşmeye başladılar. ${ }^{52} 17$. yüzyılda da topluma açılarak halkla kaynaşma yoluna gittiler. Böylece şehir sakinlerinden olan kalıcı yarı askeri bir unsura dönüştüler. Yeniçeri ağaları, birbirinden kız alıp vermekle şehirde güçlü aileler meydana getirdiler. Bu ailelerden şehirde âyanlık mevkii elde edenler oldu. Bu ailelerden, bazı fertleri Kale dizdarlığı, kethüdalık ve yeniçeri ağalığı gibi makamlarda görev yapan Afifi, Zeytun, Aseli, ve Hindiye aileleri ön plana çıkmıştır. ${ }^{53}$

Devlet bu askerleri, Sultana ait özel vergilerin toplanmasında, mukaddes şehre gelen ziyaretçilerin, tüccarların ve yolcuların kullandığı ana yolların emniyetini sağlamada, ${ }^{54}$ sancakların ve diğer vilayetlerin askerleri ile ortaklaşa olarak Hac kafilelerinin güvenliğini sağlamada istihdam ediyordu. ${ }^{55}$

17. yüzyılın ikinci yarısında iltizam düzeninin ortaya çıkmasından sonra asker ağaları, Kudüs Sancağı'nda güçlü bir yerel merkezi güç oldular. Çünkü mal sahipleri bazı malları elde etmek için belli bir güce ihtiyaç duyuyordu. İhtiyaç duydukları güç yeniçeri ağalarında mevcuttu. $\mathrm{Bu}$ da asker ağalarının yönetime ve devlet işlerine müdahalelerini arttırmıştır. ${ }^{56}$

49 K.Ş.S., 200. s. 133.

50 K.Ş.S., 200. s. 275; K.Ş.S., 201. s. 242.

51 BOA, A.DVNSMHM. d.,115, s.707, h. 3030.

52 Abdülkerim Rafik, The Province of Damascus 1723-1783, Beirut, 1966,s.21-22.

53 K.Ş.S., 200. s. 163; K.Ş.S., 231. s. 54.

54 K.Ş.S., 203. s.178; H.A. Gibb ve harold Bowen, a.g.e., C: I. s.127.

55 BOA, A.DVNSMHM. d.,114, s.582, h. 2601; K.Ş.S., 201. s. 128.

56 BOA, TS.MA.d., 9939. 115;El-Bart Havrani, El-Islâhü'l-Osmanî ve Siyasâti'l-Ayân, Mecelletü'l-İctihâd-2000. (105-142), s. 106-107. 
1702-1705 kriz yıllarında asker ağaları, âyanlarla birlikte mutasarrıfın sancağa girmesini engellediler. Devlet 1706'da aldığı bir kararla onları cezalandırarak bir kısmını şehirden uzaklaştırdı ve Şam Kalesi'ne gönderdi. ${ }^{57}$ Diğer bir kısmını şehrin ekonomik ve sosyal dokusunu korumak adına şehirde bıraktı.

1706 y1lında Devlet bölgedeki otoritesini yeniden sağlamlaştırmak, düzeni sağlamak ve Cerde Askeri'nin güvenliği için yerel hiçbir bağlantısı olmayan yeni bir ordu gönderdi. ${ }^{58}$ Devlet bu orduyu, yerel askerlerle birlikte bir denge unsuru olarak kullanmıştır. Fakat yerel askerler, sancaktaki çıkarları ve nüfuzları üzerinde bir tehdit olarak gördükleri bu yeni icraatı hoş karşılamadılar.

Yerel askeri ağalar, yeni güçlerin, yerlerini alıp iktidarın nimetlerinden faydalanmalarına müsaade etmediler. 1709 yılında yerel askerlerle kapıkulu askerleri arasında kırk gün süren ve her iki tarafin anlaşmasıyla sona eren çatışmalar meydana geldi. ${ }^{59}$ Devletin bu olaylardan sonra yaptığ 1 icraatlar kapıkulu askerlerini ve onların kale içerisindeki varlıklarını destekler niteliktedir. Zira devlet kapıkulu askerlerinin isteğiyle İslam Paşa'yı, paralı askerlere destek verdiği gerekçesiyle azlederek Kudüs sancak mutasarrıflığ görevine indirmiştir. ${ }^{60}$ Aynı şekilde kapıkulunun kanına helal fetvası vermekle itham edilen Hanefî müftüsü Muhammed Lutf'u, fitne çıkarmaya tahrik olarak değerlendirilerek sürgüne göndermiştir. Bu karar şehrin âyanlarından bazılarını da kapsayacak şekilde uygulanmıştır. ${ }^{61}$

Devletin, şehirdeki yerel yeniçerilere ve paralı askerlere bir de kapıkulu askerlerini eklemesi çeşitli sıkıntılara uygun zemin hazırladı.1709-1731 yılları arasında, bir taraftan yerel yeniçeriler ile paralı askerler, diğer taraftan yerel yeniçeriler ile kapı kulu askerleri arasında yaşanan altı kriz süreci medana geldi. ${ }^{62} \mathrm{Bu}$ çekişmelerde hiçbir grup diğerine galip gelemedi. Bu çatışmalar, her iki tarafın, çatışmanın sebeplerini son sözün sahibi devlete arz etmesiyle son bulurdu. Devlet her çatışmada yaşanan olayın mesuliyetini bir takım Ağalara yüklerdi, sürgüne gönderirdi ya da makamlarından azlederdi. Örneğin Fazlüddin Aseli Ağa'nın 1721 'de fitneye sebep olma ithamılla azledilmesinden sonra yerine Hamdân b. Ahmed Zeytun getirildi. ${ }^{63}$

Yerel askerlerin tekrarlanan girişimlerine rağmen devlet kapıkulundan oluşan bir askeri güç oluşturma kararından geri adım atmadı. Yerel askerler 1731 yılında onları kaleden kovmayı başarınca, devlet kaleye yeni kuvvetler göndermiştir.

57 BOA, A.DVNSMHM.d.,115, s.700, h. 3017.

58 Raşid. a.g.e., s.202-203, 232.

59 BOA, A.DVNSMHM.d.,115, s.707, h. 3030; K.Ş.S., 205. s.195, 200.

60 El-Halili, Tarihu'l-Kuds, a.g.e., s.218.

61 BOA, A.DVNSMHM.d.,115, s.700, h. 3017.

62 Es-Salihi, Yevmiyyât, a.g.e., s.160, 176, 215-216; K.Ş.S., 220. s. 51.

63 K.Ş.S., 216. s. 99-100. 
Yerel askerler kapıkulu askerlerinin kaleye yerleştirilmesine karşı çıkmalarının bedelini, vazifelerinin onlardan alınarak yeni ailelere verilmesiyle ödediler. Aseli ve Hindî aileleri kendilerine başka askerî vazifeler aramaya başladı. Fazlüddin Aseli Ağa ise sancak miralaylığı görevine geçti ve vefat edene kadar bu görevi sürdürdü. Vefatından sonra oğlu Abdullah Ağa, Muhammed Hindiye Ağa ile girdiği rekabeti kazanarak babasının makamına geçmeyi başardı.

Osmanlı Devletinin yaptığ icraatlar ile askeri ailelerin otoritesini elinden alma ve nüfuzlarını sınırlamadaki gücü 'Teracimehli'l-Kuds fi'lkarn es-saniaşera el-Hicri” kitabında ortaya çıkmaktadır. Zira kitabın müellifi şehirde yaşanan olaylardaki rollerine rağmen bazı şahsiyetleri âyanlardan saymamıştır.

Devlet, yerel askeri kuvvetlerin yanında sorumlu tutulduğu görevleri ve devletin emirlerini uygulayan bir askeri gücü sancağa yerleştirmeyi başarmıştır. Bunların üstlendikleri görevlerin en önde geleni, geniş bir katılımla senenin büyük bölümünü Cerde Askeri'ne refakat ederek geçirmeleriydi. 1724 yılında İran'la yapılan savaşta sultanın ordusuna çağrılmışlardır. ${ }^{64} 1739$ 'da devlet Şam vilayet merkezindeki fitneyi bastırmak için mütesellimden 200 asker göndermesini istedi. ${ }^{65} \mathrm{Bu}$ askerler Zâhiru'1 Ömer ile karşı yapılan bastırma harekâtına katıldılar ayrıca farklı senelerde defalarca çağrılmıştır. ${ }^{66}$

\section{Bedevî Kabilelerin Şeyhleri}

Bedevî kabilelerin çoğu, sancak çevresindeki bölgelere yerleşmiştir. Osmanlı Devleti Kudüs Sancağı'nı kendine bağladıktan sonra sancak dışındaki Hac kalelerinin erzak yollarının, Kudüs Hac kafilesinin geçiş güzergâhının ve ana Hac yoluna çıkan yolların geçtiği bölgelerde yaşayan bedevi kabileler ile devlet, hem bu yolların hem de genel güvenliğin sağlanması için antlaşmalar yaptı. Bu görev karşılığında bu kabilelere senelik surre ödedi. Her Kabilenin güvenliği ile sorumlu olduğu bölgeler belirlendi. Ukba Kabilelerinden olan Mesa'id Kabilesi Kudüs'ten Belka'ya, oradan da Kerek Kalesi'ne kadar olan alandan sorumlu tutuldu. ${ }^{67}$ Atiye kabilelerinden olan Vuheydat Kabilesi de Halil şehrinden Ar'ur'a, oradan da Akabe'ye kadar olan yolların güvenliğinden mesul tutuldu. ${ }^{68}$

Devlet ile sancaktaki kabilelerin ilişkileri kısmi bir anlayış ile devam etti. $\mathrm{Bu}$ kabileler Devletin temsilcileri ile beraber, devlete karşı gelenlere karşı bazı savaşlara katıldılar. ${ }^{69}$ Ancak 17. asrın sonu ve 18. asrın başında bu kabilelerden ba-

64 BOA, A.DVNSSSKT.d., 32, s.327, h. 1448.

65 K.Ş.S., 230. s. 23.

66 Ahmet El-Budiri, Havadis dimaşk El Yavmiye, Dimaşk, 1993, s.147.

67 Abdulkadir El-ceziri, Ed-durar el-feraidelmunezme fi ahber El-Hac ve Mekke mukerme, C: II, Beyrut, 2002, s.1368.

68 A.g.e. s.1338-1342.

69 Gibb ve harold Bowen, a.g.e., C: I. s.323; Karl Barbir, Ottoman Rule in Damascus, New Jercey, 1979, s.174. 
zıları hacılara saldırıp mallarını çalınca ilişkiler bozulmuştur. ${ }^{70}$ Bazıları ise çevre köylerdeki çiftçilerden ${ }^{71}$ ve şehirdeki tüccar ve ziyaretçilerden vergi almaya başladılar. ${ }^{72}$ Bunlar askerlere de saldırdılar.1699 yılında devletin, Ramle mütesellimliği görevine atadığı, Kudüs âyanlarından Akîl Ağa'yı öldürdüler. ${ }^{73}$

Bedevî Kabileler ile devlet arasındaki ilişkilerin bozulması, 18. yüzyılda Kudüs Sancağı'ndaki vergi aidatlarının Cerde Askeri'ne tahsis edildiği, Cerde Askeri'nin güvenliği için sancaktaki asker sayısının artırıldığı bir zamana denk gelmiştir. Aynı zamanda bu vakit Kudüs ve el-Halil şehirlerinde Cerde Askeri'ne tahsis edilen iktisadî faaliyetlerin yoğunlaştığ $1^{74}$ ve sancaktan toplanıp Hac kalelerine giden malzemelerin nakli için güvenli bir güzergâha ihtiyacın arttığı bir zamanda devletin bu görevi üstlenebilecek bedevi kabilelere olan ihtiyacı daha da artmıştır.

Ana Hac yoluna ulaşan güzergâhların güvenliğini sağlamaları, Devleti bedevî kabilelere yönlendiren tek sebep değildir. Bedevî kabileler vergilerin toplanmaS1 noktasında da sıkıntı çıkarmışlardır. ${ }^{75}$ Onların çiftçilere ve şehri ziyarete gelen turistlere yaptığı saldırılar, şehri ziyarete gelen Hıristiyanların azalmasına ${ }^{76}$ ve çiftçilerin bölgeyi terk ederek köylerine dönmesine sebep olmuştur. ${ }^{77}$ Şehre ziyarete gelen yabancılar ve çiftçiler sancağın en önemli gelir kaynakları arasındaydı.

Devlet 18. yüzyılın ilk yarısında bedevi kabileleri eski anlaşmalarda belirlenmiş olan sancakla ilgili yükümlülükleri yerine getirmekle sorumlu tutmuştur. Devlet bu kabilelerin şeyhlerini Ğafiru'l Hac unvanını ve Hac kalelerine erzak taşıma işi gibi kârlı bir işi kendilerine vermek suretiyle yanlarına çekmeye çalışmıştır. ${ }^{78}$

Bazı kabileler devletle işbirliğine giderek önceki anlaşmalara bağlılıklarını ilan ettiler. Bu sebeple Devletin güvenini kazanan Vuheydat Kabilesi, sancaktan Hac kalelerine erzak taşıma işi gibi kârlı bir işin kendilerine verilmesi suretiyle devlet tarafından ödüllendirilmişlerdir.1715 yılında sancak mutasarrıfı Recep Paşa'nın yaptıkları buna örnek teşkil etmektedir. ${ }^{79}$

Devlet temsilcileriyle Vuheydat Kabilesi arasındaki bu uyum, kabilenin devlet nezdindeki itibarını arttırmış ve kabile şeyhlerinin sancaktaki önemli mev-

70 K.Ş.S., 200. s. 175; K.Ş.S., 207. s. 67, 189-190; El-Halili, Tarihu'l-Kuds, a.g.e., s.155; El-Hüseyni, a.g.e. s. 145

71 BOA, A.DVNSŞKT.d., 48, s.329; K.Ş.S., 199. s. 513; K.Ş.S., 200. s. 65; K.Ş.S., 201. s. 99.

72 BOA, A.DVNSŞKT.d., 32, s.225; K.Ş.S., 201. s. 452 ; K.Ş.S., 203. s. 179.

73 K.Ş.S., 201. s. 1.

74 El-Halili, Tarihu'l-Kuds, a.g.e., s.195.

75 BOA, AE.SMST.II., 6529.

76 K.Ş.S., 209. s. 265.

77 K.Ş.S., 200. s. 17.

78 K.Ş.S., 135. s. 412.

79 K.Ş.S., 209. s. 277-278. 
kilere gelmelerini sağlamıştır. Aynı sebeple şehrin kadısı, Argup Köyü ile Lud Köyü arasında yaşanan anlaşmazlığın halledilmesi için Vuheydat Arapları'nın şeyhi Muhlis bin Vâkid'i görevlendirmiş, o da bu görevi başarıyla yerine getirmiştir. ${ }^{80} 1704$ yılında İslam Paşa'nın Kudüs'ü kuşatıp toplarla dövdüğü sırada Vuheydat şeyhi Muhammed Vuhaydi gelerek iki y1ldır ödenmeyen vergileri ödeme işini üstlenmiştir. Bunun için kardeşini ve yeğenini rehin bırakan ${ }^{81}$ Vuheydat şeyhi, mutasarrıfa verdiği sözü de yerine getirmiştir. ${ }^{82}$

Mesa'id Kabilesi gibi bazı kabileler, daha önceki anlaşmalara bağlı kalmadıkları için devletin gazabına uğradılar. Bu nedenle sancak mutasarrıflarıyla Şam valilerinin birçok askeri hamlesine maruz kaldılar. Bunların karşılaştığı en şiddetli hücum, 1713 yılında Şam valisi Nasuh Paşa tarafından, Eriha yakınlarında Mesa'id Kabilesi'ne karşı yapılmıştır. Kabilenin şeyhi Abdulkadir ve birçok oğlu kaynakların tabiriyle âleme ibret olması için öldürülmüştür. ${ }^{83}$

Devlet ayrıca daha önceki anlaşmalara bağlı kalmayan bedevî kabilelerin para kaynaklarını kurutmaya gayret etmiştir. Sancak yöneticilerinden, bedevilerin hacılardan çaldıkları malları sancakta satmalarına engel olmalarını, yakalanan malların mümkünse sahiplerine iade edilmesini istedi. ${ }^{84}$ Bedevi kabilelerin artan Hac kafile soygunlarıyla sancakta çalıntı mal satımı revaçtaydı. 1705 senesinde bedevi kabilelerin Cebrin Kalesi'nde mal sakladığını haber alan devlet, Şam valisini Kürt Mehmet Paşa bizzat kaleye gitmekle görevlendirmiş; o da kaleyi içindekilerle birlikte ateşe vermiştir. ${ }^{85}$

Devlet, kabilelere ateşli silahların ulaşmasını önlemeleri noktasında temsilcilerini sıkıştırmıştır. Devletin Yafa Limanı'ndaki kaleleri inşa etmesindeki hedeflerinden biri de bu kabilelerin korsanlardan ateşli silah satın almalarını önlemekti. ${ }^{86}$ Ancak bu kabileler silahları satın alacakları yeni bir kaynağa ulaşmayı başardılar. Bu kaynak Devletin mültezimlerinden biri olan ve iltizam bölgesi Hayfa ve Akka'yı kapsayan Zahiru'l Ömer'dir. Fransa'dan pamuk karşılığında silah alan Zahiru'l Ömer, bu silahları bedevî kabilelere satıyordu. ${ }^{87}$

Devletin bazı zamanlarda başarısız olması Şam valisi Esad Paşa'yı, (17431756) daha önce yapılan antlaşmaları devlet adına bozmaya sevk etti. Zira paşa sadece büyük kabilelere surre ödedi, içerisinde Vuheydat Kabilesi’nin de bulun-

80 K.Ş.S., 200. s. 42.

81 K.Ş.S., 201. s. 27; K.Ş.S., 202. s. 219.

82 K.Ş.S., 202. s. 211.

83 Kamil Cemil Aseli, El-Kudüs fi tarih, Amman, 1992, s.112.

84 Muhammed El-Halili, El-Fetava El-Kubra el-musanna bi'l-fetava El-Haliliyye, Kudüs, 1998.C: I, s.318; Es-Salihi, Yevmiyyât, a.g.e., s. 30, 61.

85 BOA, TS.MA.d. 2945/47; Raşid. a.g.e., C: II, s.587; Rafik, Filistin, a.g.e., s.764.

86 BOA, TS.MA.d. 7551/33; K.Ş.S., 230. s. 36; A.g.s., 232. s. 14.

87 K.Ş.S., 201. s. 39; Abbud Es-Sabbağ, Er-Ravdü'z-Zahir fi Tarihi Zahir, Erbid, 1999,s. 35. 
duğu küçük kabilelere ödeme yapmadı. Paşanın Şam Valiliği’nden azledilmesinden sonra 1757 senesinde bedevi kabilelerin eline firsat geçti. Özellikle de bu sene bölgede büyük bir kuraklık yaşanmıştı. Bedevi kabileler Hac kafilesi ve Cerde Askeri’ne büyük çaplı bir saldırı düzenlediler. Bu saldırı Hac kafilesi tarihinde yapılan en büyük ve en kanlı saldırıydı. Bazı kaynaklara göre aralarında Sultan II. Mahmut'un kız kardeşi ile Cerde Askeri emiri Musa Paşa'nın bulunduğu40 bin hac1 hayatını kaybetti. ${ }^{88}$

Devlet bedevi kabileleri daha önceki anlaşmalarla yükümlü tutma konusunda kısmî bir başarı elde etmiştir. Devletin bazı askeri harekâtları birtakım engellerle karşılaştı. Bunlardan en bariz olanı Devletin, sancağın doğusu ve güneyinde çöl arazilerinde yer alan kabileleri yakalamaya gücünün yetmemesidir.

88 El- Muradi, a.g.e.,C: III, s.132-134, C: II, s.61; El-Budiri, a.g.e., s.70, 186-187; El-Müncid. a.g.e., s. 79; Karl Barbir, a.g.e., s.105-106. 


\section{Sonuç}

Devlet âyanlara bölgedeki temsilcileri ile halk arasinda terk ettikleri arabulucu görevini tekrar vererek onları yanında tutmayı başarmıştır. Devlet ekonomik gücü ile göreve getirme ve görevden azletme yetkisini kullanarak âyanların, başkentte, Şam ve sancaktaki devlet temsilcileriyle iyi ilişkiler kurmasını sağlamıştır.

Devlet sancakta kapıkulundan oluşan ve sancağın yönetimiyle ilgili işlere müdahale edip görevlerini aksatan yerel askerlerle birlikte denge unsuru olan icracı bir kuvvet oluşturmayı başarmıştır. Devlet sancağın içinde ve dışında yürüttüğü askeri harekâtların çoğunda Kudüs'te bulunan bu kuvvetten istifade etmiştir. Bunlar, devletin emirlerine bağl1 kalarak görevlerine ve devlete olan sadakatlerini ortaya koymuşlardır.

Devlet bedevi Arapların sancakta çıkardıkları kargaşaları sonlandırmaya ça1̧ştı. Yaptığı antlaşmalarla onları ziraat alanlarından uzaklaştırmaya, yolların emniyetini sağlamaya çalıştı. Hac kalelerine gıda nakliyatı, karlı ticaret antlaşmaları ve bazı unvanlar vererek etrafa zarar vermelerini önledi. Ders vermek için askeri harekâtlar düzenledi, gelir kaynaklarını kurutmaya gayret etti ve silahlanmalarını engellemeye çalıştı.

Ğudeyye ailesinden olan âyanlar, Kasım ve Akil ailelerinden olan ağalar ve Vadihat Kabilesi gibi kabileler devletle işbirliği içinde oldukları için sancak tarihinde önemli görevler üstlenmişlerdir. Buna karşl1ık Vefai ailelerinden olan âyanlar, Hindiye Ailesi'nden olan ağalar ve Mesa'id Kabilesi gibi kabileler ise devletin kararlarına karşı çıkmaları sebebiyle bu görevlere gelememişlerdir. 


\section{Kaynakça}

\section{Arşiv Kaynakları}

\section{A) Başbakanlık Osmanlı Arşivi (BOA) \\ Defterler}

Atik Şikayet Defterleri, (A.DVNSŞKT. d.), Nr. 32,37,48.

Mühimme Defterleri. (A.DVNSMHM. d.), Nr.114, 115.

\section{Belgeler}

Ali Emiri Tasnifi (AE.)

CevdetTasnifi (C.)

İbnüleminTasnifi (İE.)

B) Kudüs Şer'iyye Sicilleri (K.Ş.S), 200-209, 216, 225, 227-230, 232.

\section{Kaynak Eserler}

Abu-Maneh, Butrus, The Husaynis: The Ris of Notable Family in 18 th Century Palestine on book Daivd Kushner: Palestine in the late Ottom anperiod, Jerusalem, 1986.

Barbir, Karl, Ottoman Rule in Damascus1708-1757, New Jercey, 1979.

El- Aseli, Kâmil Cemil, El-Kudüs fi tarih, Amman, 1992. , Vesaik makdisiyye tarihiye, Amman, 1983.

El-Bediri, Ahmed, Havadis dimaşk El Yavmiye, Dimaşk, 1993.

El-Ceziri, Abdulkadir, Ed-Durar el-feraidelmunezme fi ahber El-Hac ve Mekke mukerme, Beyrut, 2002.

El-Halili, Muhammed, El fetava el-kubra el-musanna bi'l-fetava El-Haliliyye, Kudüs, 1998. , Tarihi'lKudsve'l-halil, Londra, 2004.

El-Hüseyni, Hasan, Teracimehli'l-Kuds fi'lkarn es-saniaşera el-Hicri, Amman, 1985.

El-Makar, Muhammed b. Cuma, El-Başat ve'lKudat fi Dımaşk, VülatüDimaşk fi'lahdi'l Osmaniye, tahkik Salahaddin El-Müncid, Dimaşk, 1949.

El-Muhibbi, Muhammed, Hulasatu'l-esar fi Âyan el-karn el-hadi aşera, Kahire, 1966.

El-Muradi, Muhammed Halil, Silkü'd-Durar fi Âyan el-karn es-sani aşera, Dimaşk, 1955.

Es-Sabbağ, Abbud, Er-Ravdü'z-Zahir fi Tarihi Zahir, Erbid, 1999. 
Es-Salihi, Muhammed İbn Kennan, El-Mevakibü'lislamiyyefi'lMemalik ve'lMehasin Eş-Şamiyye, Dimaşk.

, Muhammed İbn Kennan, Yevmiyyâtü'ş-Şâmiyye, Dımaşk, t.y.

Gibb, H.A., Harold Bowen, İslamic Society and the west, Oxford Üniversitesi, 1957.

Hasavna, Esma, “Ailet el-Kuds el-mutanefizafi'l-karn es-saminaşera”, (Yayımlanmamış Doktora Tezi), Yarmuk Üniversitesi, Ürdün, 2005.

Havrani, El-Bart, El-bilad Alarapiye fi El-ahd El-Osmani, Dimaşk, 1996.

, El-Islâhü'l-Osmanî, Siyasâti'l-Âyan, Mecelletü'l-İctihâd, 2000.

Rafik, Abdülkerim, "Filistin fi El-Ahd El-Osmani” el-Mevsuâtu'lFilistiniye, cilt II, Beyrut, 1990.

Raşid, Mehmed, Tarih-i Raşid, İstanbul.

Rosen, Minna, "The Naqib Al-ashraf Rebellion in Jerusalem and its repercussion on the city's (Thimmis)", Asian and African Stadies, 19, 1984.

Schilcher, Linda, Families in Politics: Damascene Factions and Estates of the 18th and 19th Centuries, Wiesbaden, F. Steiner, 1985. 